\title{
Loss of imprinting in IGF2 in colorectal carcinoma assessed by microdissection
}

\author{
SHIORI MAENAKA ${ }^{1}$, TETSUROU HIKICHI ${ }^{1}$, MIWA A. IMAI ${ }^{2}$, \\ TOSHINARI MINAMOTO $^{3}$ and EI KAWAHARA ${ }^{1}$ \\ ${ }^{1}$ Department of Laboratory Sciences, School of Health Sciences, Kanazawa University Faculty of Medicine; \\ ${ }^{2}$ Department of Health Science, Ishikawa Prefectural Nursing University; ${ }^{3}$ Division of Diagnostic \\ Molecular Oncology, Cancer Research Institute, Kanazawa University, Japan
}

Received September 27, 2005; Accepted November 24, 2005

\begin{abstract}
To ascertain the implications of loss of imprinting (LOI) of the insulin-like growth factor II gene (IGF2) for carcinogenesis, the precise frequency of LOI in colorectal carcinoma was examined using a laser capture microdissection method, and compared to the matched normal colorectal mucosa. LOI was examined by PCR-restriction fragment length polymorphism in combination with direct sequencing. The status was assigned as imprinting when PCRRFLP showed only one band or sequence with a single peak, otherwise cases were classified as LOI. LOI was found in 13 of 24 informative cases of carcinoma (54\%), which was higher than the ratios reported previously. LOI was also found in the normal colorectal mucosae in 14 cases $(58 \%)$. The LOIs in carcinomas and in the normal mucosae were closely correlated: 10 of 13 LOI-positive carcinomas showed LOI in the matched normal mucosae. These results suggest that LOI of IGF2 in colorectal carcinoma and LOI in the background mucosa play important roles in carcinogenesis.
\end{abstract}

\section{Introduction}

The insulin-like growth factor II gene (IGF2) is imprinted genetically, and normally only the paternal allele is expressed. IGF2 is expressed at a high level in the fetus, and plays an important role in fetal growth and development, but its expression is down-regulated after birth (1-3). When it occurs in the germ cell, loss of imprinting (LOI) of the IGF2 causes overexpression of IGF2, leading to Beckwith-Wiedemann syndrome, in which macroglossia and splanchnomegaly appear (4). As LOI of IGF2 is advantageous for cell proliferation, it has been suggested that LOI in somatic cells is involved in

Correspondence to: Dr Ei Kawahara, Department of Laboratory Sciences, School of Health Science, Kanazawa University Faculty of Medicine, 5-11-80 Kodatsuno, Kanazawa 920-0942, Japan

E-mail: kawahara@kenroku.kanazawa-u.ac.jp

Key words: genomic imprinting, insulin-like growth factor II gene, colorectal carcinoma, microdissection tumorigenesis $(1-3,5)$. It has been reported that LOI of IGF2 occurs at high frequency in a wide variety of carcinomas, including colorectal carcinomas, gastric carcinomas, esophageal carcinomas, and hepatocellular carcinomas, although the reported incidence of LOI in these tumors shows considerable variation (6-13). LOI of IGF2 seems to play a unique role in tumorigenesis in colorectal carcinoma. LOI in the normal mucosa has been reported to be a potential marker of colorectal cancer risk, as the incidence of LOI in the normal mucosa with colorectal carcinoma is 3 -fold higher than that in normal mucosa $(14,15)$.

It is necessary to determine the precise incidence of LOI to ascertain its implications in carcinogenesis, but this is hampered by a number of problems. First, carcinoma tissues resected surgically contain normal cells, including lymphocytes, fibroblasts, and endothelial cells, which have the normal genome distinct from that of carcinoma cells, and it is extremely difficult to obtain the pure carcinoma genome from carcinoma tissues by surgical resection. Due to contamination, the reported LOI should be less frequent than predicted. The laser capture microdissection (LCM) method has been developed to allow pure carcinoma cells to be obtained more easily and precisely (16). Using LCM, loss of heterozygosity (LOH) of tumor suppressor genes in carcinoma cells has been investigated and the frequency determined using this method was higher than those obtained by analysis of whole tissue $(17,18)$. Similarly, normal cells can be eliminated using LCM to analyze LOI precisely. However, the frequency of LOI using LCM has not been reported previously. Second, by PCRrestriction fragment length polymorphism (RFLP), a commonly used approach for quantifying imprinted alleles that distinguishes the ApaI polymorphic site, the presence of heteroduplexes in the PCR products cannot be recognized correctly by the endonuclease (19), and methods other than PCR-RFLP are necessary for correct assessment of LOI. DNA sequencing could be helpful for identifying LOI, as it has been used to detect a single sequence or heterogeneous sequences in a PCR product although it is poorly suited for quantification (19).

Here, we examine the precise incidence of LOI in colorectal carcinoma and matched normal colorectal mucosa; our results indicated higher frequencies of LOI in colorectal carcinoma and the matched normal mucosa than reported previously. 
Table I. Primer pairs and restriction endonuclease used for the semi-nested PCR-RFLP.

\begin{tabular}{|c|c|c|c|}
\hline Primer pairs & Sequence & $\begin{array}{c}\text { Restriction } \\
\text { endonuclease }\end{array}$ & $\begin{array}{l}\text { Fragment size (bp) } \\
\quad \text { total (digest) }\end{array}$ \\
\hline \multicolumn{4}{|l|}{1 st run } \\
\hline sense & 5'-CTTGGACTTTGAGTCAAATTGG-3' & ApaI & $292(231+61)$ \\
\hline antisense & 5'-GGTCGTGCCAATTACATTTCA-3' & & \\
\hline \multicolumn{4}{|l|}{2 nd run } \\
\hline sense & 5'-CTTGGACTTTGAGTCAAATTGG-3' & ApaI & $257(196+61)$ \\
\hline antisense & 5'-GGTTTTCATGCTCTGTCCTC-3' & & \\
\hline
\end{tabular}

\section{Materials and methods}

Materials. Tissue samples were obtained from 53 patients with colorectal carcinoma. Portions of carcinoma tissues and nontumor mucosa were cut out and frozen immediately after surgery at Kanazawa University Cancer Research Hospital. The tissues were stored at $-80^{\circ} \mathrm{C}$ until analysis. All patients gave informed consent before sample collection according to our institutional guidelines.

PCR-RFLP. Genomic DNA from normal tissues was extracted using a DNA isolator PS kit (Wako, Osaka, Japan) in accordance with the manufacturer's recommendations. Total RNA was extracted from the normal or carcinoma tissues by the acid guanidinium phenol chloroform method (20), and contaminating DNA was digested by DNAse I (Takara, Tokyo, Japan). Aliquots of $1 \mu \mathrm{g}$ of extracted total RNA in a volume of $20 \mu \mathrm{l}$ were converted to cDNA using AMV reverse transcriptase (Promega, Madison, WI). Reverse transcription reaction was performed for $30 \mathrm{~min}$ at $42^{\circ} \mathrm{C}$ and then heated for $5 \mathrm{~min}$ at $99^{\circ} \mathrm{C}$ to inactivate the enzyme. Genomic DNA and cDNA were amplified by the PCR method with the primer pairs for exon 9 of human IGF2 (10) listed in Table I. The PCR product was re-amplified by semi-nested PCR with the same sense primer and the other antisense primer for microdissected specimens (Table I). As the amplified area was restricted to the exon, fragments of the same length were amplified from genomic DNA and cDNA. Digestion of contaminating genomic DNA by DNAse I was confirmed by PCR to amplify the exon-intron spanning region of the integrin $B 5$ gene (21). Analysis of ApaI polymorphism in the IGF2 gene was then performed. The PCR products were digested with ApaI (Toyobo, Osaka, Japan) for $3 \mathrm{~h}$ at $37^{\circ} \mathrm{C}$ and run on $2 \%$ agarose gels containing ethidium bromide. The electrophoresis patterns appeared as three bands for heterozygotes, where the restriction enzyme recognition sequence was present in one allele and absent in the other. Digital images of the bands scanned into a computer were analyzed using NIH image.

Laser capture microdissection. Colorectal tissues were frozen and embedded in OCT compound (Tissue-tech. Torrance, USA). Sections $10-\mu \mathrm{m}$ thick were cut and fixed with $70 \%$ ethanol on silanized slides (Dako Japan, Kyoto, Japan) for $10 \mathrm{~min}$. A laser capture microdissection system (LCM, LM100, Olympus, Tokyo, Japan) was used to obtain individual

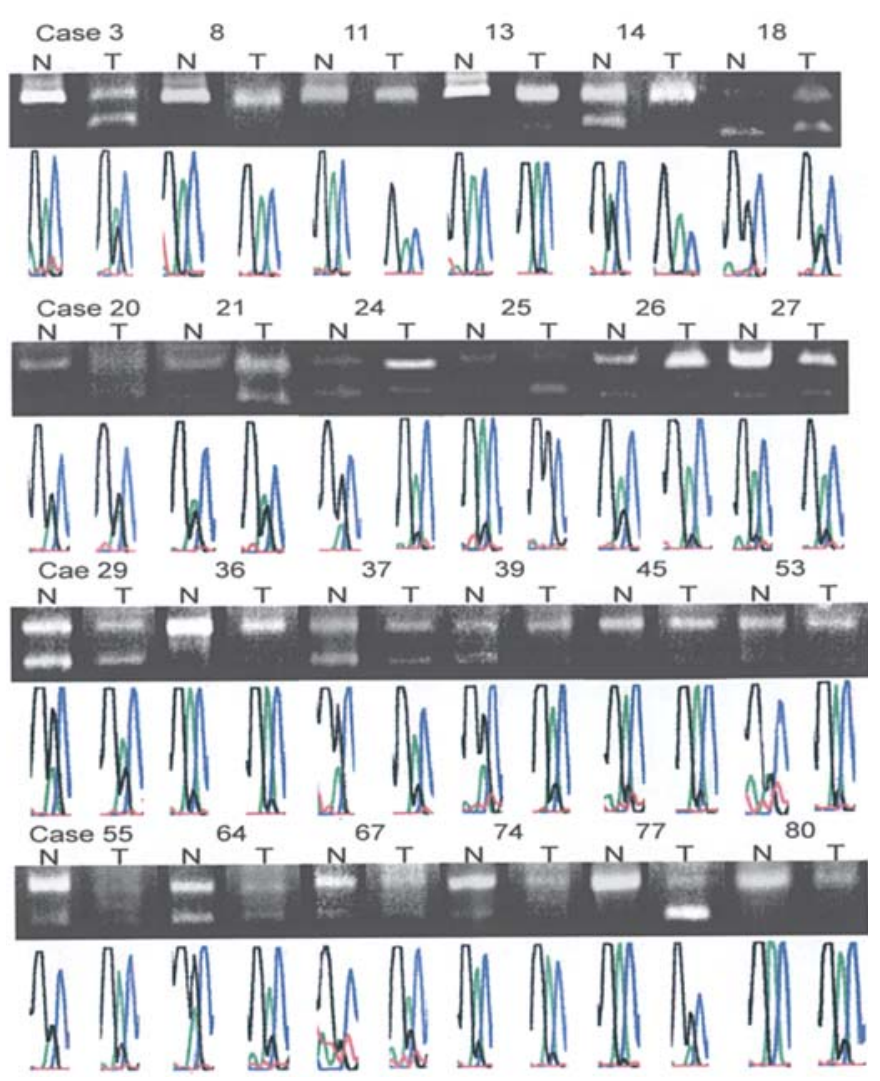

Figure 1. PCR-RFLP analysis using ApaI polymorphism and sequencing for whole tissues of normal mucosa and microdissected colorectal carcinomas. PCR products were digested with $A p a \mathrm{I}$ and run on 2\% agarose gels. In the electropherogram, green shows adenine, black shows guanine, and red shows thymine. N, normal mucosa; $\mathrm{T}$, tumor.

carcinoma cells in the tissue sections stained with Kernechtrot (Merck, Darmstadt, Germany). Between 100 and 1000 cells were collected on each plastic cap (CapSure ${ }^{\mathrm{TM}}$ LCM Caps, Arcturus, Mountain View, CA). To extract total RNA from microdissected carcinoma cells, we used a PicoPure ${ }^{\mathrm{TM}}$ RNA isolation kit (Arcturus) in accordance with the manufacturer's instructions. All specimens were assessed histologically by a pathologist (E. Kawahara).

Statistical analysis. Statistical analyses were performed using the $\chi^{2}$ test. 
Table II. The status of imprinting or loss of imprinting (LOI) in informative cases using whole normal tissues or laser capture microdissected carcinoma cells evaluated by PCR-RFLP in combination with direct sequencing. ${ }^{\mathrm{a}}$

\begin{tabular}{|c|c|c|c|c|c|c|}
\hline \multirow[b]{2}{*}{ Case } & \multicolumn{3}{|c|}{ Normal tissue } & \multicolumn{3}{|c|}{ Carcinoma cells } \\
\hline & $\begin{array}{l}\text { PCR } \\
(\% \mathrm{~A})\end{array}$ & $\begin{array}{l}\text { Sequence } \\
(\% \mathrm{~A})\end{array}$ & Status & $\begin{array}{l}\text { PCR } \\
(\% \mathrm{~A})\end{array}$ & $\begin{array}{c}\text { Sequence } \\
(\% \mathrm{~A})\end{array}$ & Status \\
\hline 3 & 100 & 100 & Imprinting & 55 & 65 & LOI \\
\hline 8 & 100 & 100 & Imprinting & 100 & 100 & Imprinting \\
\hline 11 & 100 & 100 & Imprinting & 100 & 100 & Imprinting \\
\hline 13 & 100 & 100 & Imprinting & 100 & 100 & Imprinting \\
\hline 14 & 60 & 53 & LOI & 100 & 100 & Imprinting \\
\hline 18 & 25 & 0 & Imprinting & 42 & 52 & LOI \\
\hline 20 & 94 & 50 & LOI & 71 & 44 & LOI \\
\hline 21 & 93 & 57 & LOI & 73 & 56 & LOI \\
\hline 24 & 46 & 24 & LOI & 66 & 81 & LOI \\
\hline 25 & 100 & 79 & Imprinting & 0 & 0 & Imprinting \\
\hline 26 & 70 & 64 & LOI & 100 & 91 & Imprinting \\
\hline 27 & 91 & 89 & LOI & 78 & 82 & LOI \\
\hline 29 & 40 & 37 & LOI & 49 & 60 & LOI \\
\hline 36 & 100 & 92 & Imprinting & 100 & 92 & Imprinting \\
\hline 37 & 40 & 40 & LOI & 64 & 77 & LOI \\
\hline 39 & 43 & 33 & LOI & 79 & 22 & LOI \\
\hline 45 & 100 & 92 & Imprinting & 100 & 93 & Imprinting \\
\hline 53 & 76 & 50 & LOI & 100 & 90 & Imprinting \\
\hline 55 & 78 & 50 & LOI & 86 & 75 & LOI \\
\hline 64 & 57 & 64 & LOI & 62 & 71 & LOI \\
\hline 67 & 81 & 40 & LOI & 81 & 69 & LOI \\
\hline 74 & 93 & 77 & LOI & 100 & 90 & Imprinting \\
\hline 77 & 100 & 95 & Imprinting & 15 & 27 & LOI \\
\hline 80 & 100 & 100 & Imprinting & 100 & 85 & Imprinting \\
\hline
\end{tabular}

aThe ratios of the densities of the top and bottom bands (top/top+bottom) by PCR-RFLP and the ratios of the height of A and G peaks $(A / A+G)$ on sequencing are listed. When there was only one band by PCR-RFLP (ratio of 0 or 100\%) or the sequence pattern showed a single peak (ratio of 0 or $100 \%$ ), the status was considered to be imprinting, otherwise the status was considered to be LOI.

\section{Results}

Genomic DNA of whole non-tumor mucosa was used for screening whether the samples were informative or not, using PCR-based ApaI polymorphism. Of the 53 colorectal carcinoma cases $(56.6 \%) 30$ were informative. All of the informative cases for which tissue sections were available for LCM (24 of 30 cases) were examined for the imprinting status in both normal mucosa and in microdissected carcinoma cells. PCR products from cDNA in the normal mucosa and carcinoma cells showed two bands or a single band on ApaI analysis, and two $\mathrm{A}$ and $\mathrm{G}$ peaks or a single $\mathrm{A}$ or $\mathrm{G}$ peak by sequence analysis (Fig. 1). Prior to determining whether the status is imprinting or LOI, the density ratio between the top and bottom bands by PCR-RFLP and the ratio of heights of $A$ and $G$ peaks by sequence analysis were measured and calculated (Table I). Samples were judged as showing LOI when two bands were seen even if the bottom bands were faint. If the top bands were faint (cases 18 and 77), we had to consider the possibility of incomplete ApaI digestion, and examined the results of sequencing analysis carefully. Cases with a single $G$ peak were considered to be imprinting (case 18). Cases with a low A peak in addition to the $G$ peak were considered to be LOI (case 77). As sequencing data indicated whether the ratio by PCR-RFLP was $<10$ or $>90 \%$, ApaI analysis in almost all cases showed only one band, and $10 \%$ was considered the background level. However, the normal mucosae of cases 25 and 80, in which peaks were within 10 to $90 \%$, were assumed to show imprinting as PCRRFLP analysis showed only one band. Thus, all cases were assumed to be assigned correctly to imprinting or LOI, and eventually we identified simple criteria for the imprinting status: when there is only one band on PCR-RFLP (ratio of 0 or $100 \%$ ) or the sequence pattern shows a single peak (ratio of 0 or $100 \%$ ), the status is considered to be imprinting; otherwise, the status is considered LOI.

LOI of IGF2 was detected in 14 of the 24 informative cases $(58 \%)$ in matched normal mucosa (Table II). Of the 24 
informative cases 13 (54\%) showed LOI using LCM (Table II). There was a significant difference between LOI-positive cases in the normal mucosa and LOI-positive cases in carcinoma cells $(\mathrm{P}<0.05)$ : 10 of 14 LOI-positive cases in the normal mucosa also showed LOI in the carcinoma cells. In two cases, the imprinting status in the normal mucosa changed to LOI in the carcinoma cells. Furthermore, there were various patterns of change; in four cases, LOI in the normal mucosa converted to imprinting in carcinoma cells (cases 14, 26, 53, and 77), and imprinting in the $\mathrm{G}$ allele converted to imprinting in the A allele in one case (case 25).

\section{Discussion}

Contamination by normal cells is a major problem in analysis of gene expression by carcinoma cells using tissue samples. Microdissection is advantageous to obtain pure carcinoma cells. In the present study, we found LOI in 54\% of microdissected colorectal carcinoma cells, which was higher than the rates of $33-44 \%$ reported previously $(6-9,14)$. This high incidence was probably due to the use of microdissection, which also enabled us to improve the evaluation of LOI. Previous studies had to take into account not only true contamination by normal cells but also the possibility of contamination. For example, cases in which one of two bands obtained by PCR-RFLP was faint were not considered to be LOI. Application of the microdissection method allows the possibility of contamination to be excluded. Using microdissection we found that cases in which one band derived from the $G$ or $A$ allele was faint represented LOI. The evaluation method seems reasonable, as partial biallelic expression would occur (22) and the imprinting status could vary within the tumor (23). Indeed, case 77 may show partial imprinting in which one band on PCR-RFLP was faint and the peak of sequence was low, but use of a precise method for quantification, such as hot-stop PCR using radioisotopes (19), would be necessary to confirm this. Yun et al (24) further suggested that variation in the incidences of LOI reported to date could have been due to partial digestion with the restriction enzyme and contamination by genomic DNA. In the present study, we used DNAse for RNA extraction and confirmed removal of genomic DNA. Direct DNA sequencing method could be applied if there was a problem of partial digestion by ApaI. Thus, the high frequency of LOI (>50\%) found here suggests that overexpression of IGF2 by LOI plays a critical role in tumorigenesis in colorectal carcinomas. However, in a few cases LOI in the normal mucosa showed the converse alteration to imprinting status in the tumor, whereas it is disadvantageous for cell proliferation. Furthermore, imprinting of the A allele in the normal mucosa was converted to imprinting of the $\mathrm{G}$ allele in one case, which seemed to be neither advantageous nor disadvantageous for cancer. These phenomena may reveal a basic feature of the diversity of these tumors.

Cui et al $(14,25)$ found LOI of IGF2 in the tumors and matched normal colonic mucosa in $30 \%$ of colorectal carcinoma patients, as compared with $10 \%$ of individuals without colorectal carcinoma, suggesting that LOI in the normal tissue may be a marker of colorectal cancer risk (15). This suggestion is similar to the concept that DNA mutation targeting oncogenesis appears in normal colon tissue and progresses toward adenoma and then carcinoma (26). Similarly, we also clarified the high incidence of LOI in the normal mucosa $(58 \%)$, and $77 \%$ of LOI-positive carcinomas showed LOI in the normal mucosa, supporting the hypothesis proposed by Cui. Other studies also showed a high incidence of LOI in matched normal mucosa of cases with LOI-positive carcinoma, ranging from 60 to $100 \%(13,14,22)$. LOI causes only a modest increase in IGF2 expression, theoretically double, but tumorigenesis may occur through alterations in intestinal maturation (27).

\section{Acknowledgements}

This study was supported by a grant from the Ministry of Education, Culture, Sports, Science, and Technology of Japan.

\section{References}

1. Falls JG, Pulford DJ, Wylie AA and Jirtle RL: Genomic imprinting: implications for human disease. Am J Pathol 154: 635-647, 1999.

2. Feinberg AP: Imprinting of a genomic domain of $11 \mathrm{p} 15$ and loss of imprinting in cancer: an introduction. Cancer Res 59: S1743-S1746, 1999.

3. Randyac LJ: Genomic imprinting and cancer. Exp Cell Res 248: 18-24, 1999.

4. Ohlsson R, Nystrom A, Pfeifer-Ohlsson S, Tohonen V, Hedborg F, Schofield P, Flam F and Ekstrom TJ: IGF2 is parentally imprinted during human embryogenesis and in the Beckwith-Wiedmann syndrome. Nat Genet 4: 94-97, 1993.

5. Sakatani T, Kaneda A, Lacobuzio-Donahue CA, Carter MG, Witzel SB, Okano H, Ko MSH, Ohlsson R, Longo DL and Feinberg AP: Loss of imprinting of IGF2 alters intestinal maturation and tumorigenesis in mice. Science 307: 1976-1978, 2005.

6. Kinouchi Y, Hiwatashi N, Higashioka S, Nagashima F, Chida M and Toyota T: Relaxation of imprinting of the insulin-like growth factor II gene in colorectal cancer. Cancer Lett 107: 105-108, 1996.

7. Takano Y, Shiota G and Kawasaki H: Analysis of genomic imprinting of insulin-like growth factor 2 in colorectal cancer. Oncology 59: 210-216, 2000.

8. Nishihara S, Hayashida T, Mitsuya K, Schulz TC, Ikeguchi M, Kaibara $\mathrm{N}$ and Oshimura M: Multipoint imprinting analysis in sporadic colorectal cancers with and without microsatellite instability. Int J Oncol 17: 317-322, 2000.

9. Nakagawa H, Chadwick RB, Peltomäki P, Plass C, Nakmaura Y and de La Chapelle A: Loss of imprinting of the insulin-like growth factor II gene occurs by biallelic methylation in a core region H19-associated CTCF-binding sites in colorectal cancer. Proc Natl Acad Sci USA 98: 591-596, 2001.

10. Wu MS, Wang HP, Lin CC, Sheu JC, Shun CT, Lee WJ and Lin JT: Loss of imprinting and overexpression of IGF2 gene in gastric adenocarcinoma. Cancer Lett 120: 9-14, 1997.

11. Kim K-S and Lee Y-I: Biallelic expression of the H19 and IGF2 genes in hepatocellular carcinoma. Cancer Lett 119: 143-148, 1997.

12. Nonomura N, Miki T, Nishimura K, Kanno N, Kojima Y and Okuyama A: Altered imprinting of the H19 and insulin-like growth factor II genes in testicular tumors. J Urol 157: 1977-1979, 1997.

13. Mori M, Inoue H, Shiraishi T, Mimori K, Shibuta K, Nakashima H, Mafune K, Tanaka Y, Ueo H, Barnard GF, Sugimachi K and Akiyoshi T: Relaxation of insulin-like growth factor 2 gene imprinting in esophageal cancer. Int J Cancer 68: 441-446, 1996.

14. Cui H, Horon IL, Ohlsson R, Hamilton SR and Feinberg AP: Loss of imprinting in normal tissue of colorectal cancer patients with microsatellite instability. Nat Med 4: 1276-1280, 1998.

15. Ransohoff DF: Cancer Developing molecular biomarkers for cancer. Science 299: 1679-1680, 2003.

16. Emmert-Buck MR, Bonner RF, Smith PD, Chuaqui RF, Zhuang Z, Goldstein SR, Weiss RA and Liotta LA: Laser capture microdissection. Science 274: 998-1001, 1996. 
17. Zhu W, Zou H, Beck A, Chervinsky D, Malik D, Brooks JJ and Tan D: Loss of heterozygosity in primary lung cancer using laser capture microdissection and WAVE DNA fragment analysis techniques. Med Sci Monit 8: 95-99, 2002.

18. Bertheau P, Plassa LF, Lerebours F, De Roquancourt A, Turpin E, Lidereau R, De Thé $\mathrm{H}$ and Janin A: Allelic loss detection in inflammatory breast cancer: improvement with laser microdissection. Lab Invest 81: 1397-1402, 2001.

19. Uejima H, Lee MP, Cui H and Feinberg AP: Hot-stop PCR: a simple and general assay for linear quantitation of allele ratios. Nat Genet 25: 375-376, 2000.

20. Chomzynski P and Sacchi N: Single-step method of RNA isolation by acid guanidinium thiocyanate-phenol-chloroform extraction. Anal Biochem 162: 156-159, 1987.

21. Kawahara E, Saito A, Kobayashi J, Maenaka S, Minamoto T, Imai MA and Oda Y: Adhesiveness of $B 5$ integrin variant lacking $\mathrm{FNK}^{767-769}$ is similar to that of the prototype containing FNKFNK $^{764-769}$. Cell Biol Int 29: 521-528, 2000.

22. Hofmann W-K, Takeuchi S, Franzen MA, Hoelzei D and Koeffler HP: Loss of genomic imprinting of insulin-like growth factor 2 is strongly associated with cellular proliferation in normal hematopoietic cells. Exp Hematol 30: 318-323, 2002.
23. He L, Cui H, Walsch C, Mattsson R, Lin W, Anneren G, Pfeifer-Ohlson S and Ohlson R: Hypervariable allelic expression patterns of the imprinted IGF2 gene in tumor cells. Oncogene 16: 113-119, 1998.

24. Yun K, Soejima H, Merrie AE, McCall JL and Reeve AE: Analysis of IGF2 gene imprinting in breast cancer by allele specific-PCR. J Pathol 187: 518-522, 1999.

25. Cui H, Onyango P, Brandenburg S, Wu Y, Hsieh C-L and Feinberg AP: Loss of imprinting in colorectal cancer linked to hypomethylation of H19 and IGF2. Cancer Res 62: 6442-6446, 2002.

26. Vogelstein B, Fearon ER, Hamilton SR, Kern SE, Preisinger AC, Leppert M, Nakamura Y, White R, Smits AM and Bos JL: Genetic alterations during colorectal-tumor development. N Engl J Med 319: 525-532, 1988.

27. Cui H, Cruz-Correa M, Giardiello FM, Hutcheon DF, Kafonek DR, Brandenburg S, Wu Y, He X, Powe NR and Feinberg AP: Loss of IGF2 imprinting: a potential marker of colorectal cancer risk. Science 299: 1753-1755, 2003. 